\title{
Erythrocyte glucose-6-phosphate dehydrogenase activity assay and affinity for its substrate under "physiological" conditions
}

A.A. Leite ${ }^{1}$ and O.C. de O. Barretto ${ }^{2}$

\section{Correspondence \\ O.C. de O. Barretto \\ Av. Pedroso de Morais, 70 \\ Apto. 101 \\ 05420-000 São Paulo, SP \\ Brasil \\ Fax: $+55-11-853-5894$}

Presented at the XIII Annual Meeting of the Federação de Sociedades de Biologia Experimental, Caxambu, MG, Brasil, August 26-29, 1998. Research supported by FAPESP and CAPES.

Received April 9, 1998 Accepted October 8, 1998

\author{
'1Faculdade de Ciências Farmacêuticas, U niversidade Estadual de Araraquara, \\ Araraquara, SP, Brasil \\ ${ }^{2}$ LIM 27, Instituto de Psiquiatria, Faculdade de Medicina, \\ Universidade de São Paulo, São Paulo, SP, Brasil
}

Erythrocyte glucose-6-phosphate dehydrogenase (G6PD) (EC 1.1.1.49) is a pentose shunt enzyme involved in the maintenance of adequate concentrations of reduced nicotinamide adenine dinucleotide phosphate (NADPH). This nucleotide, together with glutathione reductase, keeps glutathione in its reduced form $(\mathrm{GSH})$, protecting the red cell against oxidative stress. There are two normal G6PD variants, G6PD B and G6PD $\mathrm{A}^{+}$, and other deficient polymorphic mutants such as G6PD $\mathrm{A}^{-}$, besides dozens of rare ones (1), some of which have been described by our group $(2,3)$.

The standard methods used to assay G6PD activity and affinity (Michaelis-Menten constant $-\mathrm{Km}$ ) for its substrate are currently performed using reaction conditions of 145 mOs and ionic strength I: $0.06, \mathrm{pH} 8.0$, at $37^{\circ} \mathrm{C}$ for activity assay and $25^{\circ} \mathrm{C}$ for $\mathrm{Km}$ determination. In the present study the enzyme activity as well as its affinity were determined under nearly physiological conditions regarding osmolarity $(290 \mathrm{mOs})$ and ionic strength (I: 0:188), $3 \mathrm{mM} \mathrm{MgCl} 2, \mathrm{pH}$ 7.34 , at $37^{\circ} \mathrm{C}$. The activity assay was performed with NADP and glucose-6-phosphate (G6P) in excess. Under physiological conditions $\left(37^{\circ} \mathrm{C}\right.$ and $\left.290 \mathrm{mOs}\right)$ there was a $10-12 \%$ decrease in the activity assay, as well as an affinity decrease of $50 \%$ when compared to the standard methods $\left(25^{\circ} \mathrm{C}\right.$ and $145 \mathrm{mOs}$ ).

Blood was collected in the preservative 
solution ACD (citric acid, citrate and dextrose), and filtered through 1:1 microgranular cellulose:alpha-cellulose. The red cells were washed in buffered saline at $4^{\circ} \mathrm{C}$ and lysed and the enzymatic assays were carried out according to standard methods $(4,5)$. The "physiological" reagent system was: $250 \mathrm{mM}$ Tris-HCl, pH 7.34, 3 mM $\mathrm{MgCl}_{2}, 0.2 \mathrm{mM}$ NADP, which, together with the hemolysate and the substrate in excess (glucose-6-phosphate - $0.6 \mathrm{mM} \mathrm{G6P)}$ gave a final osmolarity of $290 \mathrm{mOs}$ with I: 0.188 ionic strength at $37^{\circ} \mathrm{C}$. G6PD purification and variant characterization were performed at $25^{\circ} \mathrm{C}$ according to standard methods $(4,5)$ (activity against substrates, electrophoresis, $\mathrm{Km}$ for G6P and NADP, Ki for NADPH, pH curve, and thermal stability) and the Km was subsequently determined again under "physiological" conditions.

Other authors have focused on the effect of isolated factors on G6PD activity and affinity (6-9). In a different approach, the present study was planned to investigate how the activity and affinity would work in a nearly "physiological" environment involving several factors, a fact that impairs comparison of our data with those reported by others.
According to the results shown in Table 1 , the studied variants showed different values in enzyme activity under "physiological" conditions $(<10.4 \%$ in G6PD B,$<12.4 \%$ in G6PD $\mathrm{A}^{+}$and $<21.5 \%$ in $\left.\mathrm{G} 6 \mathrm{PD} \mathrm{A}^{-}\right)$. The deficient variant G6PD $\mathrm{A}^{-}$appeared to be more sensitive to "physiological" conditions than the normal variants, a fact that, allied to its decreased activity, may enhance its difficulty in carrying out its metabolic functions, with impaired red cell performance.

The enzyme affinity for its physiological substrate glucose-6-phosphate was decreased when the "physiological" reagent system was employed, although the higher temperature used should theoretically facilitate the affinity. The ionic strength seems to play an important role in determining the affinity, impairing the access of the substrate to the active site of the enzyme.

In conclusion, the reduced activity of G6PD $\mathrm{A}^{-}$, taken together with its diminished affinity for its substrate, obtained under "physiological" conditions, in fact reflects the actual pentose shunt rate. This suggests a lower actual NADPH generation as well, which is crucial mostly in G6PD-deficient individuals, whose NADPH availability is poor.

Table 1 - Glucose-6-phosphate dehydrogenase (G6PD) activity and affinity for its substrate under standard (WHO) and "physiological" conditions

G6P, glucose-6-phosphate. *IU/g Hb, ** $\mu \mathrm{M} / \mathrm{I}$.

\begin{tabular}{|c|c|c|c|c|c|}
\hline & \multirow{2}{*}{$\begin{array}{l}\text { Osmolarity } \\
\text { mOs }\end{array}$} & \multirow{2}{*}{$\begin{array}{c}\text { lonic } \\
\text { strength (I) }\end{array}$} & \multirow{2}{*}{$\begin{array}{c}\mathrm{G} 6 \mathrm{PD} \\
\text { activity }\left(37^{\circ} \mathrm{C}\right)^{*}\end{array}$} & \multicolumn{2}{|c|}{ G6PD Km for G6P** } \\
\hline & & & & $25^{\circ} \mathrm{C}$ & $37^{\circ} \mathrm{C}$ \\
\hline \multicolumn{6}{|l|}{ G6PD type B } \\
\hline WHO & 145 & 0.086 & $12.6 \pm 1.3(100 \%)$ & $47.6 \pm 2.6(100 \%)$ & $62.3 \pm 6.3(131 \%)$ \\
\hline "Physiological” & 290 & 0.188 & $11.3 \pm 1.2(89.6 \%)$ & & $95.1 \pm 10.3(200 \%)$ \\
\hline \multicolumn{6}{|l|}{ G6PD type $A^{+}$} \\
\hline WHO & 145 & 0.086 & $11.7 \pm 1.6(100 \%)$ & $49.1 \pm 1.2(100 \%)$ & $62.9 \pm 4.4(128 \%)$ \\
\hline "Physiological" & 290 & 0.188 & $10.2 \pm 1.3(87.2 \%)$ & & $94.4 \pm 4.4(192 \%)$ \\
\hline \multicolumn{6}{|l|}{ G6PD type $A^{-}$} \\
\hline WHO & 145 & 0.086 & $1.4 \pm 0.4(100 \%)$ & $50.0 \pm 1.3(100 \%)$ & $63.5 \pm 4.8(127 \%)$ \\
\hline "Physiological" & 290 & 0.188 & $1.1 \pm 0.1(78.5 \%)$ & & $95.4 \pm 10.5(191 \%)$ \\
\hline
\end{tabular}




\section{References}

1. Beutler E (1995). Glucose-6-phosphate dehydrogenase deficiency and other enzyme abnormalities. In: Beutler E, Lichtman MA, Coller BS \& Kipps TJ (Editors), Williams Hematology. 5th edn. McGraw-Hill, New York, 564-581.

2. Barretto OC de O \& Nonoyama K (1987). $\mathrm{Gd}(+)$ Cuiabá, a new rare glucose-6-phosphate dehydrogenase variant presenting normal activity. Human Genetics, 77: 201202.

3. Barretto OC de O \& Nonoyama K (1991). $\mathrm{Gd}(-)$ Carapicuiba, a rare glucose-6-phosphate dehydrogenase variant associated with moderate enzyme deficiency and chronic hemolysis. Brazilian J oumal of Medical and Biological Research, 24: 133-139.

4. World Health Organization Scientific
Group (1967). Standardization of procedures of the study of glucose-6-phosphate dehydrogenase. World Health Organization Technical Report Service, 366: 1-53.

5. Beutler E, Mathai CK \& Smith J E (1968). Biochemical variants of glucose-6-phosphate dehydrogenase giving rise to congenital nonspherocytic hemolytic disease. Blood, 31: 131-150.

6. Cohen P \& Rosemeyer MA (1969). Human glucose-6-phosphate dehydrogenase: Purification of the erythrocyte enzyme and the influence of ions on its activity. European J ournal of Biochemistry, 8: 1-7.

7. Luzzatto L (1973). Studies of polymor- phic traits for the characterization of populations: African populations South of the Sahara. Israel J ournal of Medical Sciences, 9: 1181-1194.

8. Babalola AOG, Beetlestone J G \& Luzzatto $L$ (1976). Genetic variants of human erythrocyte glucose-6-phosphate dehydrogenase. Kinetic and thermodynamic parameters of variants $A, B$ and $A^{-}$in relation to quatemary structure. J ournal of Biological Chemistry, 251: 2993-3002.

9. Yoshida A (1980). A contradiction between in vivo and in vitro activities of normal and variant glucose-6-phosphate dehydrogenase. Hemoglobin, 4: 769-780. 


\section{Rio de Janeiro Cell Bank}

\section{Human and Animal Cell Biotechnology Services}

- Deposit and Distribution of Cell Lines

- Cell Cryopreservation

- Development and Distribution of Human and Animal Primary Cell Cultures

- Development of New Monoclonal Antibody Secreting Hybridomas

- Monoclonal Antibodies, in Cell Culture Supernatants or Purified

- Identification of Microbiological Contaminants

- Decontamination of Cell Lines

- Cytotoxicity Tests

- Characterization of Cell Lines

- Training in "in vitro" Culture of Human and Animal Cells

- Consultation Assistance in Cell Culture

\section{Contact us for specific services not listed above}

Banco de Células do Rio de Janeiro - BCRJ Programa Avançado de Biologia Celular aplicado à Medicina - PABCAM Hospital Universitário Clementino Fraga Filho - HUCFF Universidade Federal do Rio de Janeiro - UFRJ

Sala 4A9, Caixa Postal 68021 CEP 21941-970 Rio de Janeiro, RJ

Tel: (021)564-2010 Ramal 249 Tel/Fax: (021)590-8736 